\title{
PENGEMBANGAN BAHAN AJAR EKONOMI TERINTEGRASI AYAT-AYAT SUCI AL-QUR'AN DAN AL- HADIST PADA SISWA KELAS X DI MA DARUSSHOLIHIN NW KALIJAGA LOMBOK TIMUR
}

\author{
Solihatun Ummah ${ }^{1}$ Muh. Fahrurrozi ${ }^{2}$ Rohaeniah Zain $^{3}$ \\ ${ }^{1}$ Mahasiswa Prodi Pendidikan Ekonomi FKIP Universitas Hamzanwadi \\ Email: james.lombok05@gmail.com \\ ${ }^{2}$ Prodi Pendidikan Ekonomi FKIP Universitas Hamzanwadi \\ Email:ozyalu@gamil.com \\ ${ }^{3}$ Prodi Pendidikan Ekonomi FKIP Universitas Hamzanwadi \\ Email: rohaeniahzain@gamil.com
}

\begin{abstract}
This study aims to determine the steps of development of integrated economic teaching materials of the holy verses of al-qur'an and al-hadist to know the result of development of integrated economic learning materials of the holy verses of al-qur'an and al-hadist on class students $X$ at MA Darussholihin NW Kalijaga. This research is a development research by adopting Borg \& Gall development model, to 7 that is, requirement analysis, planning, early product format development, initial product validation, product revision, field trial, revision of final product of research subject is class X MA Darussholihin NW Kalijaga as many as 30 students. Data collected in this research is qualitative and quantitative data of data collection instrument include questionnaire of student response of technical analysis of data used in this research is static formula for validation of teaching materials. Based on validation results from material experts and high quality linguists with the number of expert material values 53 linguists 37 average score of $90 \%$ with a high or valid height. Student's response to teaching materials is very high with average percentage of $85.15 \%$ overall components in the range of $82 \%$ - $100 \%$ with very responding category.
\end{abstract}

Keywords: Development of Integrated Economic, Learning Materials of the Holy Verses of Al-qur'an and Al-hadist.

\begin{abstract}
ABSTRAK
Penelitian ini bertujuan untuk mengetahui langkah-langkah pengembangan bahan ajar ekonomi terintegrasi ayat-ayat suci al-qur'an dan al-hadist untuk mengetahui hasil pengembangan bahan ajar ekonomi terintegrasi ayat-ayat suci al-qur'an dan al-hadist pada siswa kelas X di MA Darussholihin NW Kalijaga. Penelitian ini merupakan penelitian pengembangan dengan mengadopsi model pengembangan Borg \& Gall, menjadi 7 yaitu, analisis kebutuhan, perencanaan produk, pengembangan format produk awal, validasi produk, revisi produk awal, uji coba lapangan, revisi produk akhir. subjek penelitian adalah kelas $\mathrm{X}$ MA Darussholihin NW Kalijaga sebanyak 30 siswa. Data yang diproleh dalam penelitian ini adalah data kualitatif dan kuantitatif instrumen pengumpulan data meliputi angket respon siswa teknis analisis data yang di gunakan dalam penelitian ini adalah rumus statistik diskriptif untuk validasi bahan ajar. Berdasarkan hasil validasi dari ahli materi dan ahli bahasa
\end{abstract}


kualitas tinggi dengan jumlah nilai ahli materi 53 ahli bahasa 37 skor rata-rata 90\% dengan tegori tinggi atau valid. Respon siswa terhadap bahan ajar di katakan sangat tinggi dengan rata-rata persentase keseluruhan komponen $85,15 \%$ yang berada pada rentang $82 \%$ - 100\% dengan kategori sangat merespon.

Kata kunci: Pengembangan Bahan Ajar Ekonomi, Terintegrasi Ayat-ayat Suci Al-qur'an dan Al-hadist.

\section{A. Pendahuluan}

Pendidikan merupakan aspek utama dalam mengembangkan diri manusia dan sebagai jembatan untuk meningkatkan pengetahuan. Sepanjang sejarah, media dan teknologi pembelajaran (lebih khusus lagi bahan ajar dalam berbagai bentuk dan jenisnya) merupakan salah satu faktor yang berpengaruh terhadap mutu pendidikan. Seiring dengan tersedianya bahan ajar, peran guru dan siswa dalam proses pembelajaran turut berubah. Guru bukan lagi merupakan satu-satunya sumber belajar, karena berbagai informasi yang di proses dari berbagai media massa dan lingkungan dimana pun kita berada akan menjadi pengarah dalam proses penemuan ilmu pengetahuan. Salah satu sumber informasi yang dapat dimanfaatkan guru maupun siswa dalam proses pembelajar adalah bahan ajar.

Bahan ajar adalah bahan-bahan atau materi pelajaran di susun secara sistematis,yang di gunakan guru dan siswa dalam proses pembelajaran (Pannen, 1995).

Ekonomi sebagai ilmu yang mempelajari bagaimana manusia memenuhi kebutuhan hidupnya tidak dapat dipisahkan dengan nilai-nilai tauhid, ramburambu halal haram dan nilai-nilai etika jelas di gariskan dalam Islam sebagai pedoman agar upaya manusia dalam melakukan kegiatan ekonomi tidak menimbulkan kerusakan dan kerugian bagi sesama dan makhluk lainnya. Pada dasarnya, pengajaran ekonomi syarat dengan nilai, baik itu nilai ketuhanan, filsafat, edukasi, teoritis maupun praktis. Nilai-nilai tersebut pada hakikatnya merupakan landasan dalam pengembangan dan perwujudan manusia seutuhnya, karenanya, pengajaran ekonomi bukan hanya bertujuan agar siswa menguasai pengetahuan semata, melainkan juga membentuk manusia yang sadar akan esksistensi dirinya sebagai makhluk Tuhan. 
Al- qur'an dan al- hadist merupakan peran penting dalam dunia pendidikan, karena di dalam materi terdapat materi yang membahas tentang pemahaman terhadap al-qur'an dan al-hadist serta hal mendasar yang harus di ketahui oleh setiap peserta didik dan bisa di amalkan dalam kehidupan sehari-hari. Penting dalam sistem pendidikan untuk membentuk karakter bangsa yang beriman, bertaqwa, berilmu dan sebagainya. Tinjauan materi peran pelaku kegiatan ekonomi.

Materi yang akan dimuat dalam bahan ajar ekonomi terintegrasi ayat-ayat suci al-qur'an dan al-hadistini yaitu materi peran pelaku kegiatan ekonomi yang akan menjelaskan tentang kegiatan ekonomi yaitu: konsumsi, produksi , distribusi, dan peran pelaku kegiatan ekonomi dan firman allah yang berkaitan di dalam bahan ajar ekonomi terintegrasi ayat-ayat suci al-qur'an dan al-hadist.

\section{Konsumsi}

Konsumsi adalam memakai atau memanfaatkan barang dan jasa dan memakan makanan yang baik, dan halal dan bermanfaat bagi manusia.

Adapun ayat dan terjemahan yang berkaitan dengan konsumsi yang terkandung di dalam al-qur'an :

\section{Al-Baqoroh : 168-169}

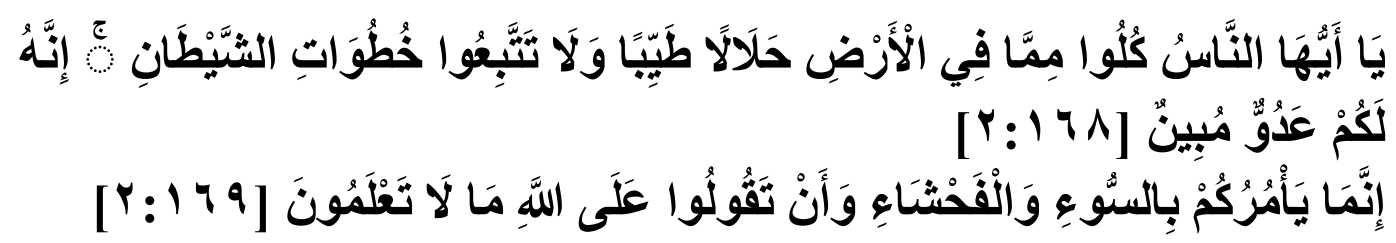

Hai sekalian manusia, makanlah yang halal lagi baik dari apa yang terdapat di bumi, dan janganlah kamu mengikuti langkah-langkah syaitan; Karena Sesungguhnya syaitan itu adalah musuh yang nyata bagimu. Sesungguhnya syaitan itu Hanya menyuruh kamu berbuat jahat dan keji, dan mengatakan terhadap Allah apa yang tidak kamu ketahui.

\section{Hadist yang terkait}




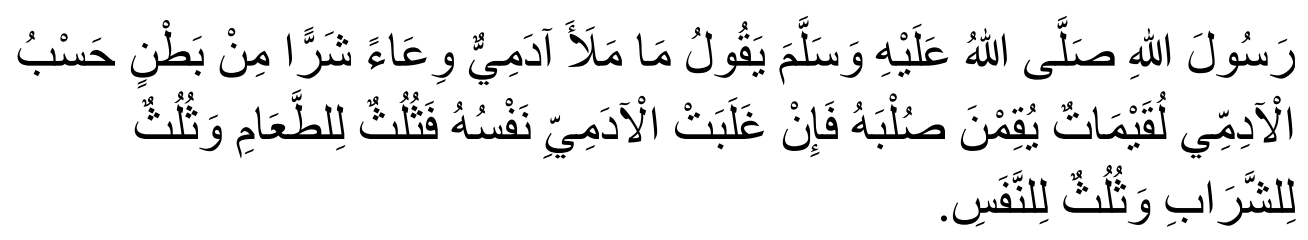

Artinya:

Rasulullah SAW bersabda:" Anak Adam tidak mengisi penuh suatu wadah yang lebih jelek dari perut,cukuplah bagi mereka itu beberapa suap makan yang dapat menegakan punggungnya, apabila kuat keinginannya maka jadikanlah sepertiga untuk makan, sepertiga untuk minum, sepertiga untuk dirinya atau udara."

\section{Produksi}

Produksi merupan membuat suata barang dan jasa. khidmatu mu'ayyanatin bi istikhdami muzayyajin min 'anashir al-intaj dhamina itharu zamanin muhaddadin(pelayanan jasa yang jelas dengan menuntut adanya bantuan pengabungan unsur-unsur produksi yang terbingkai dalam waktu yang terbatas). Pandangan Rawwas di atas mewakili beberapa definisi yang ditawarkan oleh pemikir ekonomi lainnya.Adapun ayat dan terjemahan yang berkaitan dengan produksi yang terkandung di dalam al-qur'an:

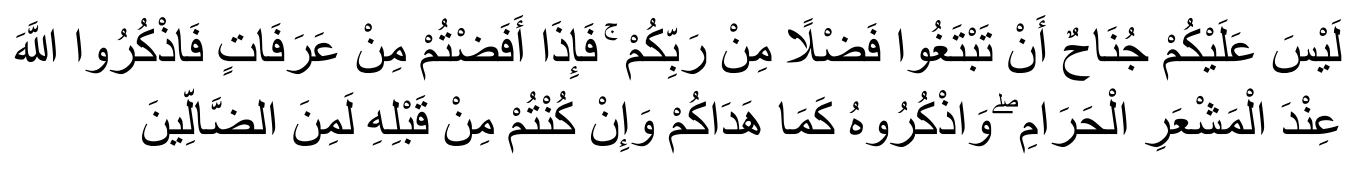

Tidak ada dosa bagimu untuk mencari karunia (rezki hasil perniagaan) dari Tuhanmu. Maka apabila kamu Telah bertolak dari 'Arafat, berdzikirlah kepada Allah di Masy'arilharam. dan berdzikirlah (dengan menyebut) Allah sebagaimana yang ditunjukkan-Nya kepadamu; dan Sesungguhnya kamu sebelum itu benar-benar termasuk orang-orang yang sesat.

\section{Distribusi}

Distribusi menurut kamus besar bahasa indonesia adalah penyaluran (pembagian, pengiriman) kepada beberapa orang atau ke beberapa tempat; pembagian barang keperluan sehari-hari (terutama dalam masa darurat) oleh pemerintah kepada pegawai negeri, penduduk, dsb. Sedangkan distribusi menurut para ahli ekonomi adalah merupakan proses penyaluran hasil produksi berupa 
barang dan jasa dari produsen ke konsumen guna memenuhi kebutuhan manusia, baik primer maupun sekunder.Adapun ayat dan terjemahan yang berkaitan dengan distribusi yang terkandung di dalam al-qur'anSurat Al-Israa' (17) : 29-30.

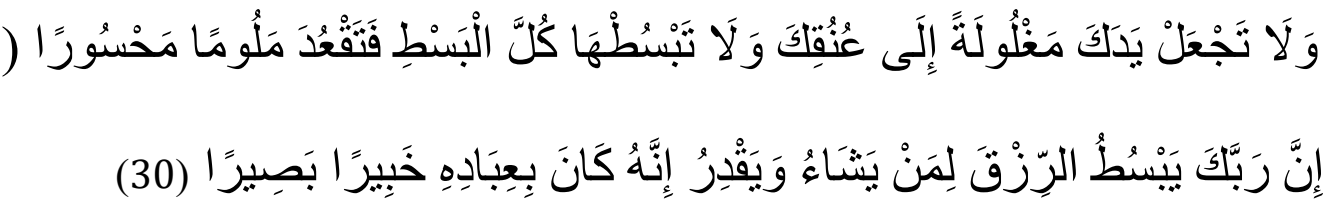

29. "Dan janganlah kamu jadikan tanganmu terbelenggu pada lehermu dan janganlah kaтu terlalu mengulurkannya. Karena itu kamu menjadi tercela dan menyesal".

30. "Sesungguhnya Tuhanmu melapangkan rezki kepada siapa yang dia kehendaki dan menyempitkannya; Sesungguhnya dia Maha mengetahui lagi Maha melihat akan hamba-hamba-Nya".

\section{B. Metodelogi Penelitian}

Model pengembangan merupakan cara yang digunakan untuk menemukan, mengembangkan dan menguji suatu produk berdasarkan prosedur yang sistematis, sehingga produk yang dihasilkan memiliki nilai ilmiah yang tinggi dan dapat dipercaya. Model pengembangan bahan ajarekonomi terintegrasi ayat-ayat suci alqur'an dan al-hadist yang digunakan diadaptasi dari model penelitian dan pengembangan Borg \& Gall.Borg \& Gall (Mijahamuddin Alwi, dkk (2013: 101) mengemukakan bahwa "Peneletian pendidikan dan pengembangan adalah suatu proses yang digunakan untuk mengembangkan dan memvalidasi produk-produk yang digunakan dalam pendidikan. "Sedangkan menurut sumber lain, metode penelitian dan pengembangan adalah "Metode penelitian yang digunakan untuk menghasilkan produk tertentu, dan menguji keefektifan produk tersebut" (Sugiyono, 2010: 407).

Prosedur penelitian dan pengembangan bahan ajar ekonomi terintegrasi ayatayat suci al-qur'an dan al-hadist yang diadaptasi dari Borg \& Gall dilaksanakan sesuai dengan tahap-tahap berikut : 


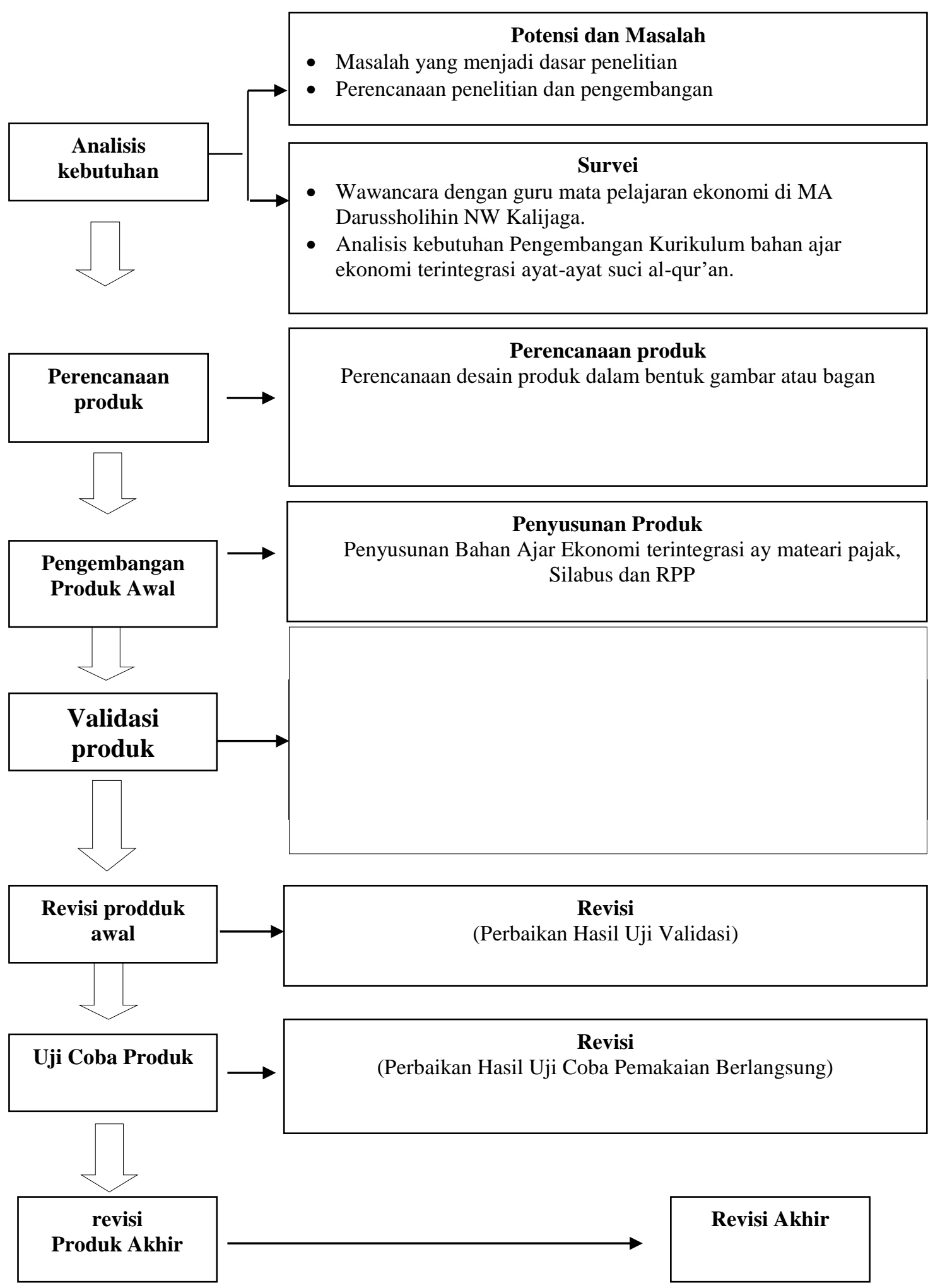

Gambar 1. Alur Pengembangan Adaptasi Borg And Gall 


\section{Analisis Kebutuhan}

Langkah awal yang dilakukan oleh peneliti dalam proses pengembangan adalah dengan mengidentifikasi kebutuhan peserta didik. Dari hasil pengamatan awal saat peneliti melakukan observasi (12 maret 2017) di MA Darussholihin NW Kalijaga pembelajaran yang dilaksanakan masih berpusat pada guru, sehingga terlihat membosankan.Pembelajaran yang terkesan membosankan tersebut kurang maksimal dalam memenuhi kebutuhan siswa, selain itu bahan ajar yang digunakan kurang memberikan pengalaman belajar. Oleh karena itu, diperlukan bahan ajar pembelajaran yang bersifat mandiri yang dapat membuat pembelajaran lebih menarik.

Dari hasil observasi peneliti pada hari yang sama bahwa pada siswa kelas $\mathrm{X}$ IPS dapat diketahui bahwa sebenarnya sebagian besar siswa memiliki bakat yang bagus dalam menyelesaikan masalah, namun karena kurang terlatihnya mereka dalam menyelesaikan masalah sehingga cara pikir mereka menjadi rendah. Untuk itu dengan mengembangkan bahan ajar ekonomi terintegrasi ayat-ayat suci alqur'an dan al-hadist pembelajaran ini diharapkan dapat memfasilitasi siswa.

\section{Perencanaan produk}

Dalam mengembangkan produk perlu adanya perencanaan desain. "Desain produk harus diwujudkan dalam gambar atau bagan, sehingga dapat digunakan untuk menilai dan membuatnya" (Sugiyono, 2012: 413). Selain itu juga, setiap desain produk selain dalam bentuk gambar atau bagan juga bisa dalam bentuk uraian ringkas, sehingga akan memudahkan pihak lain untuk memahaminya.

Proses perancangan dalam pengembangan bahan ajar ini meliputi pembuatan:

a. Tujuan

Perlu dibuat tujuan yang jelas pada pengembangan bahan ajar ekonomi pembelajaran ini yakni untuk memfasilitasi siswa.

b. Isi/kurikulum

Dalam penelitian ini perlu dikaji tentang materi apa yang akan termuat dalam bahan ajar pembelajaran ini yakni menganalisis peran pelaku kegiatan ekonomi.

\section{Pengembangan produk awal}


Pada tahap ini mulai disusun atau dibuat bentuk bahan ajaryang akan dikembangkan. Setelah pembuatan produk, dilakukan penilaian atau validasi produk bahan ajar yang dibuat.Validasi produk dapat dilakukan dengan meminta beberapa ahli dalam bidangnya untuk menilai produk yang dibuat.Hasil validasi ataupun masukan dari ahli dikaji dan dijadikan sebagai panduan untuk memperbaiki rancangan produk yang dibuat sebelum diuji cobakan.

\section{Validasi produk}

Setelah pembuatan produk, dilakukan penilaian atau validasi produk bahan ajar yang dibuat.Validasi produk dapat dilakukan dengan meminta beberapa ahli dalam bidangnya untuk menilai produk yang dibuat. Hasil validasi ataupun masukan dari ahli dikaji dan dijadikan sebagai panduan untuk memperbaiki rancangan produk yang dibuat sebelum diuji cobakan.

\section{Revisi produk awal}

Tahapan ini dilakukan dengan tujuan untuk mendapatkan desain bahan ajar ekonomi terintegrasi ayat-ayat suci al-qur'an dan al-hadist yang valid. Revisi dilakukan bilamana desain belum mencapai tingakatan valid.Pihak yang berperan penting pada tahap ini adalah ahli materi, dan ahli bahasa yang menentukan apakah desain perlu direvisi ataukah sudah sesuai melalui hasil lembar validasi yang sudah diisi.

Tindak lanjut dari kegiatan di atas, tergantung hasil yang diperoleh dari ahli tetapi dapat dibagi menjadi tiga kemungkinan, yaitu:

a. Apabila hasil analisis data validasi menunjukkan Prototipe-1 sudah valid dan efektif tanpa revisi, maka siap untuk dilakukan uji coba di lapangan.

b. Apabila hasil analisis data validasi menunjukkan bahwa Prototipe-1 valid dan efektif digunakan dengan revisi kecil dan akan dilakukan revisi kecil pada Prototipe-1. Sehingga Prototipe-1 yang sudah direvisi disebut prototipe-2 dan siap untuk diujicobakan di lapangan.

c. Apabila hasil data validasi menunjukkan prototipe-1 adalah tidak valid atau tidak efektif, maka dilakukan revisi besar. Hasil revisi prototipe-1 harus divalidasi kembali oleh ahli dan praktisi. Kegiatan validasi ini dimungkinkan terjadi siklus sampai diperoleh prototipe yang memenuhi kriteria kevalidan. 
Prototipe yang memenuhi kriteria kevalidan selanjutnya disebut prototipe-2 dan siap untuk dilakukan uji coba lapangan.

\section{Uji coba lapangan}

Setelah produk dinilai layak oleh ahli materi dan ahli bahasa maka selanjutnya dilakukan uji coba lapangan yaitu kepada siswa yang merupakan pengguna dari produk yang dikembangkan. Dalam uji, coba ini melibatkan 30 siswa kelas X IPS. Uji coba lapangan ini bertujuan untuk mengetahui kelayakan bahan ajar yang dikembangkan.

\section{Revisi produk akhir}

Setelah dilakukan uji coba lapangan Pada tahap ini dilakukan revisi akhir untuk menyempurnakan produk yang dibuat jika ada kekurangan atau kesalahan yang perlu diperbaiki.Bahan ajar ekonomi terintegrasi ayat-ayat suci al-qur'an dan al-hadistini dapat digunakan pada saat proses pembelajaran di dalam kelas maupun digunakan siswa mandiri di rumah.

\section{Hasil Penelitian}

Data di dapatkan dengan menggunakan dua tahap yaitu data hasil validasi ahli dan hasil uji coba lapangan dalam pengembangan bahan ajar ekonomi terintegrasi ayat-ayat suci al-qur'an dan al-hadist.

\section{Data hasil validitas tim ahli}

a. Validasi Ahli materi

Penilaian validator ahli materi terhadap bahan ajar ekonomi terintegrasi ayat-ayat suci al-qur'an dan al-hadist adalah untuk menggali komentar dan saran, baik secara tertulis maupun lisan dengan cara melakukan diskusi tentang produk yang di kembangkan.

Pada tahap ini di laksanakan dengan menyerahkan produk pembelajaran yang di kembangkan untuk dievaluasi dengan instrumen penilaian.Validasi ini di lakukan untuk mengetahui kelayakan baik dari semua sisi materi.Penilaian, komentar, dan saran revisi dari validator di gunakan sebagai acuan untuk merivisi produk awal sebelum di uji cobakan kepada siswa.

b. Validasi ahli bahasa 
Penilaian ahli bahasa terhadap bahan ajar ekonomi terintegrasi ayat-ayat suci al-qur'an dan al-hadist untuk memperoleh kevalidan bertujuan untuk menggali komentar dan saran, baik secara tertulis maupun lisan tentang produk yang di kembangkan.

Pada tahap ini di laksanakan dengan menyerahkan produk pembelajaran yang di kembangkan untuk di evaluasi dengan instrumen penilian. Data validasi diperoleh dengan cara memberikan produk dalam bentuk draft bahan ajar apakah sesuai dengan ejaan yang disempurnakan.

Tabel 1:

Hasil Validasi Bahan Ajar Ekonomi

\begin{tabular}{cccc}
\hline No & Validasi & Aspek & Skor \\
\hline 1 & Validasi oleh ahli materi & Kelayakan isi bahan ajar & 53 \\
\hline 2 & Validasi oleh ahli bahasa & Kejelasan susunan kalimat & 37 \\
\hline \multicolumn{2}{c}{ Skor } & & $\mathbf{9 0}$ \\
\hline
\end{tabular}

Berdasarkan data validator tim ahli pada tabel di atas di proleh skor 53 pada aspek kelayakan isi yang divalidasi ahli bahasa diproleh skor 37 sehingga total poin yang diproleh adalah 90 poin. Ini merupakan hasil penjumlahan semua skor yang di berikan oleh validator.Yang berarti validitas isi bahan ajar yang di kembangkan sangat tinggi.

\section{Data hasil uji coba}

Data hasil uji coba yang di maksud adalah data hasil uji coba lapangan, yakni dengan melakukan uji coba pada siswa kelas X. Uji coba dilakukan di MA Darussholihin NW Kalijaga pada tanggal 20 juli 2017 sampai dengan 3 uji coba dilakukan setelah validasi produk dan uji coba terbatas yang kemudian dilanjutkan dengan melakukan revisi. Pada tahap uji coba ini, produk yang di kembangkan dalam pembelajaran, hal ini di lakukan untuk mengetahui kesiapan produk buku bahan ajar dalam kegiatan belajar mengajar. Data yang di peroleh sebelum di uji coba diperoleh data 30 orang siswa sebagai subjek uji coba.

\section{Data hasil angket respon siswa terhadap bahan ajar}

Data respon siswa terhadap produk diperoleh setelah siswa belajar menggunakan bahan ajar ekonomi terintegrasi aya-ayat suci al-qur'an dan al- 
hadist.Untuk memperoleh data digunakan angket respon siswa dengan melibatkan 30 orang responden. Data yang mengenai respon siswa di gunakan untuk mengetahui sejauh mana siswa menanggapi produk bahan ajar yang di gunakan dalam proses pembelajaran. Dari setiap komponen diperoleh poin rata-rata respon siswa antara 22 sampai 30 dengan persentase rata-rata respon siswa 85,15\%.

Data poin angket respon siswa diproleh dari penjumlahan jawaban yang diberikan responden. Jumlah perolehan poin keseluruhan respon siswa yang sudah dikumpulkan adalah 281 poin jika di persentasekan menjadi 85,15\% yang berarti siswa sangat merespon produk bahan ajar yang di kembangkan.

\section{Pembahasan Hasil Penelitian}

Pada bagian ini akan dibahas proses dan hasil yang diperoleh dalam penilitian ini menggunakan model pengembangan Borg and Goll dengan 7 tahap yang sudah disederhanakan, yaitu analisis kebutuhan, perencanaan, pengembangan formal produk awal, validasi produk, revisi produk tahap awal, uji coba lapangan, dan revisi produk akhir. Sebelum dilakuakan uji coba terlebih dahulu bahan ajar divalidasi oleh dua orang ahli yaitu ahli materi dan ahli bahasa. Hasil validasi dari kedua ahli dianalisi sehingga menghasilkan nilai $90 \%$ yang berarti validitas isi bahan ajar sangat tinggi.

Setelah diperoleh hasil validasi selanjutnya dilakukan uji coba. Pada penilitian ini hanya dapat dilakukan uji coba lapangan. Uji coba dolakukan dikelas X MA Darussholihin NW Kalijaga dengan 30 orang siswa. Berdasarkan hasil angket respon siswa sangat merespon bahan ajar ekonomi terintegrasi ayat-ayat suci al-qur'an dan al-hadist rata-rata respon siswa adalah $85,15 \%$ yang diperoleh dari jumlah perolehan dibagi jumlah poin maksimal dikali 100\% hasil yang berada pada rentang $82 \%$ - 100\% dengan kategori sangat merespon. Dengan demikian dapat disimpulkan respon siswa terhadap bahan ajar sangat baik atau sangat merespon.

Proses belajar mengajar menggunakan bahan ajar ekonomi terintegrasi ayatayat suci al-qur'an dan al-hadist tidak selamanya berjalan dengan lancar. Ada beberapa hambatan yang dapat muncul dan sering terjadi diantaranya siswa tidak 
memanfaatkan waktunya dengan baik dan kurangnya minat dan motivasi siswa. Hambatan ini disebabkan karna beberapa siswa tersebut tidak terpokus pada materi yang dipelajari faktor penghabat lain adalah kurangnya ketersediaan waktu karna pembelajaran dengan menggunakan bahan ajar ekonomi terintegrasi ayatayat suci al-qur'an dan al-hadist membutuhkan waktu yang lebih banyak untuk belajar dan membahas materi yang tekait dengan sikap siswa juga memerlukan waktu untuk menjawab pertayaan yang diberikan dan berdiskusi dengan kelompoknya tentang apa yang ditemukan disekitarnya.

\section{E. Simpulan}

Berdasarkan hasil penelitian pengembangan bahan ajar ekonomi terintegrasi ayat-ayat suci al-qur'an dan al-hadist pada siswa kelas X MA Darussholihin NW Kalijaga dapat diambil kesimpulan bahwa dalam penelitian ini menghasilkan bahan ajar ekonomi terintegrasi ayat-ayat suci al-qur'an dan al-hadist.

Bahan ajar yang di kembangkan pada penelitian ini pada materi peran pelaku kegiatan ekonomi telah di nilai valid atau layak untuk di gunakan dari segi ahli materi, 53\% dan ahli bahasa 37\% sehingga total yang di proleh $90 \%$ dengan masing-masing kategori tinggi atau valid. Respon siswa dapat dikatakan dalam kategori tinggi dengan rincian nilai rata-rata $85,15 \%$ yang berada pada rentang $82 \%$ - $100 \%$ dengan masing-masing kategori tinggi.

\section{F. Daftar Pustaka}

\section{Al-Quran al-Karim}

Amri dan Ahmadi. 2010. Kontruksi Pengembangan Pembelajaran. Jakarta: PT. Prestasi Pustaka Raya

Hamdani, 2011.Strategi Belajar Dan Pembelajaran. Bandung: Pustaka Setia.

Huda, Nurul. 2006. Pengenalan Eksklusif Ekonomi Islam. Jakarta: Perpustakaan Nasional.

Huda, Nurul. 2009. Ekonomi Makro Islam. Jakarta: Perpustakaan Nasional.

Matsna, moh. 2004 Al- Qur 'An dan Hadist. PT. Karya Toha Putra. Semarang Indonesia

Sugiyono. 2010. Metode Penelitian Kuantitatif Kualitatif dan R\&D. Bandung: Alfabeta

Sugiyono. 2012. Metode Penelitian Kombinasi (Mixed Methods). Bandung: Alfabeta 